\title{
ZJAWISKO MOBBINGU MIĘDZYUCZNIOWSKIEGO A WARTOŚCI WYNIESIONE Z DOMU RODZINNEGO ${ }^{1}$
}

Streszczenie: Artykuł zawiera informacje na temat przemocy szkolnej w kontekście prawidłowego przekazu wartości. Przeanalizowano definicję pojęcia mobbing oraz opisano role, jakie odgrywają w nim sprawca i ofiara przemocy. W dalszej części przytoczono wyniki badań dotyczących mobbingu uczniowskiego w różnych krajach oraz wyszczególniono stosowane formy przemocy w szkole. Opisano wybrane programy profilaktyczne mające na celu ograniczenie mobbingu. Poruszono problematykę wartości mogących zminimalizować ryzyko, że dziecko stanie się ofiarą przemocy lub samo będzie mobberem.

Słowa klucze: przemoc, agresja, mobbing, ofiara mobbingu, mobber, osobowość mobbera, programy antymobbingowe, wartości

\section{Wprowadzenie}

Brak podstawowych wartości w życiu człowieka powoduje poważne zagrożenia społeczne. Oblicza tych zagrożeń ujawniają się w postaci dokonywanych przez młodych ludzi aktów przemocy wobec swoich rówieśników - zwłaszcza w szkole. Problemy, z którymi styka się nauczyciel, wiążą się przede wszystkim z tym, jak definiuje on przemoc uczniowską, gdyż sposób myślenia o mobbingu będzie implikował określony sposób działania. Jeżeli wychowawca położy nacisk na zmianę niepożądanego zachowania bez odwołania się do wartości, istnieje duże ryzyko, że uczeń podda się „zabiegom pomocowym”, ale po powrocie do dotychczasowego środowiska powróci do standardowego sposobu funkcjonowania.

Celem artykułu jest zwrócenie uwagi na związek między prawidłowym przekazem wartości w domu rodzinnym a przeciwdziałaniem zachowaniom mobbingowym w szkole.

\section{Co to jest mobbing?}

Każdy był kiedyś ofiarą lub świadkiem przemocy. Problematyczne wydaje się jednak rozstrzygnięcie, co i dla kogo jest przemocą. Badacze włoscy, opisując zjawisko mobbingu,

\footnotetext{
1 Referat wygłoszony podczas I Międzynarodowego Lądzkiego Sympozjum Pedagogicznego pt. „Współczesne problemy wychowawcze w perspektywie aksjologicznej”, które obyło się w Lądzie nad Wartą w dniu 21 czerwca 2014 roku.
} 
posługują się pojęciem violenze, odnoszącym się do zachowań brutalnych. W Japonii używa się terminu ijime, co znaczy drażnić się z kimś (Rigby 2010, s. 39-40). Szerokie ujęcie tego terminu zaproponował Ken Rigby, określając mobbing jako „umyślne nadużywanie władzy bądź siły w relacjach międzyludzkich" (Rigby 2010, s. 28). W tym rozumieniu władzy mogą nadużywać nie tylko osoby pozostające w relacji zwierzchności wobec innych, tak jak rodzice, nauczyciele, dyrektorzy itd., ale też osoby będące w relacjach symetrycznych np. uczniowie wobec siebie. Takie sytuacje zdarzają się w grupie rówieśniczej najczęściej w sytuacji, kiedy w momencie pojawienia się konfliktu niektóre z dzieci odkrywają, że mogą osiągnąć coś szybciej niż inne „wykorzystując sytuację”, która daje im władzę. W taki sposób często stają się prześladowcami. Nie można też wykluczyć sytuacji, że złośliwe znęcanie się może być aktem jednorazowym.

Do opisu przemocy w relacjach rówieśniczych stosuje się najczęściej trzy kategorie: zachowania agresywne (np. w sytuacji konfliktów), prześladowanie jednostek i dokuczanie im (ang. bullying) oraz mobbing, czyli uporczywe, zbiorowe znęcanie się kilku osób nad wybranymi ofiarami. Jeżeli prześladowanie jednostki przybiera formę powtarzających się w dłuższym czasie zachowań, terminów bulling i mobbing używa się zamiennie. Zjawisko to rzadziej opisywane jest jako harassment (nękanie) lub ganging up someone (sprzysięganie się przeciwko komuś) (Piekarska 2008).

Warto wspomnieć, że termin mobbing pochodzi od angielskiego słowa mob tłumaczonego dosłownie jako „motłoch, tłuszcza” i oznacza tyle, co napadać na kogoś, napastować, oblegać (Olweus 2007). Osoba doświadczająca przemocy jest wykluczana ze społeczności i upokarzana. Procesy mobbingu przebiegają zazwyczaj w ukryciu. Sprawcy znęcający się nad swoimi ofiarami nie chcą być zidentyfikowani. Natomiast ofiary przemocy nie znajdują wsparcia i przeżywają ten stan w samotności. Osoby biorące udział w tym procederze, zarówno sprawcy, jak i ofiary, prawie zawsze wysyłają jakieś sygnały. Powinny być one prawidłowo odebrane i zinterpretowane przez dorosłych, którzy powinni potraktować je jako punkt wyjścia do wyjaśnienia i rozwiązania zaistniałej sytuacji. Zdarza się, że nauczyciele bagatelizują problem, gdyż jest on niespecjalnie rozpoznawany w szkole, co zdecydowanie utrudnia podjęcie szybkich i skutecznych oddziaływań.

\section{Przyczyny mobbingu}

Dotychczasowe analizy nie dają jednoznacznej odpowiedzi na pytanie o źródła zachowań przemocowych. Charles Cofer i Mortimer Appley wyróżniają cztery koncepcje dotyczące przyczyn zachowań agresywnych: instynkt, reakcję na frustrację, nabyty popęd oraz zachowania agresywne jako wyuczone wzmacnianie (Grochulska 1982, s. 6-25). Zygmunt Freud twierdził, że człowiek, przychodząc na świat, zostaje wyposażony w dwie potężne siły instynktowe, którymi są: eros - instynkt życia, i tanatos - instynkt śmierci. Człowiek rodzi się zatem $z$ instynktem do walki, która jest konieczna do przetrwania. Skłonność do agresji, według tej koncepcji, powstała na drodze ewolucji (Aronson i in. 1997, s. 496-498).

Inne źródło powstawania zachowań agresywnych opisuje koncepcja frustracji - czyli agresji rozumianej jako niezaspokojenie jakiejś potrzeby z powodu okoliczności zewnętrznych, konfliktu lub przeszkody. Człowiek może zmniejszyć pojawiające się napięcie poprzez repertuar własnych zachowań np. przez zachowania agresywne (Aronson i in. 1997). 
Zachowania przemocowe mogą być też skutkiem wyuczonego wzmacniania. Albert Bandura w swoich badaniach w 1963 roku wykazał, że niektórych zachowań można się nauczyć bez udziału nagród, ale wywołać je można tylko nagrodami. Można nauczyć dzieci zachowań agresywnych, których nie będą uzewnętrzniały w warunkach normalnych, ale jedynie pod wpływem zachęty. Do głównych czynników wpływających na proces uczenia się zalicza kontakty społeczne, obserwację oraz naśladowanie modeli (Pervin 2005, s. 96). Bandura twierdził, że ogromną rolę w kształtowaniu zachowań agresywnych odgrywa obecność odpowied niego wzorca wywołującego proces naśladownictwa. Na uwagę zasługuje fakt, że nie tylko rodzice dostarczają modeli zachowania. Młody człowiek przyswaja również zachowania nauczycieli, idoli sportowych, gwiazd telewizyjnych oraz starszych kolegów. Dziecko dowiaduje się, że agresja jest społecznie akceptowana, co może spowodować, że przyjmie w przyszłości tego typu zachowanie, gdyż zauważy korzystny efekt takiego postępowania. Przemoc w telewizji i jej wpływ na dzieci jest terenem niezwykle eksplorowanym badawczo. W latach sześćdziesiątych XX wieku grupa dzieci uczestniczyła w badaniach psychologicznych dotyczących oglądania w telewizji scen przemocy z udziałem dorosłych. Wykazały one, że agresja płynąca z ekranu ma bezpośredni wpływ na zachowanie dzieci. Aktualnie prowadzone przez John Coie i Kenneth Dodge w różnych krajach podłużne obserwacje dziecięcych nawyków oglądania telewizji mają na celu uchwycenie związku między liczbą oglądanych scen przemocy a wzrostem zachowań agresywnych. Autorzy ci na podstawie uzyskanych wyników sformułowali tezę, iż w zdecydowanej większości przypadków oglądanie programów telewizyjnych pełnych przemocy wywołuje wzrost zachowań agresywnych u dzieci w okresie do około trzeciego roku życia (Guerin, Hennessy 2008, s. 19-20). Naukowcy w latach osiemdziesiątych naszego stulecia dowiedli, że im brutalniejsze sceny człowiek ogląda w dzieciństwie, tym częściej jako nastolatek lub dorosły włącza do repertuaru swoich zachowań przemoc, a częste oglądanie przemocy w mediach obniża jego wrażliwość na tego typu sytuacje (Aronson i in. 1997).

Autorzy J. Coie i K. Dodge zwracają także uwagę na związek pomiędzy agresją fizyczną a ubóstwem (Guerin, Hennessy 2008, s. 18). Wielu badaczy traktuje biedę jako czynnik ryzyka, który zgodnie z jedną z hipotez oddziaływa raczej na rodziców małych dzieci. Opiekunowie, doświadczając stresu związanego z zapewnieniem godziwych warunków rodzinie, doznają ubóstwa i powiększają ten stres. Ma to wpływ na dorosłych, na ich skuteczne oddziaływania wychowawcze oraz jakość więzi rodzinnych (Guerin, Hennessy 2008, s. 19).

Zachowania agresywne mogą pojawić się więc wszędzie tam, gdzie występuje duże napięcie, a ludzie nie potrafią zachować się w sposób nieinwazyjny. Zawsze łamią one podstawowe wartości człowieka, takie jak bezpieczeństwo i obrona własnego terytorium. Są przyczyną silnych napięć, emocji i urazów. Zaburzają relacje, niszczą więzi i w konsekwencji mogą wywołać zachowania u tych ludzi, do których są kierowane.

\section{Portret psychologiczny lidera i ofiary mobbingu}

Często słyszymy o zjawisku przemocy starszych uczniów nad młodszymi, jednak przemoc szkolna dotyczy zwykle dzieci z tej samej klasy. Dręczenie występuje najczęściej wśród osób tej samej płci. Jeżeli dochodzi do konfliktu miedzy osobami odmiennej płci, to prawdopodobnie będzie to znęcanie się chłopców nad dziewczynkami (Rugby 2008, s. 45). 
Należy wspomnieć, iż sprawca przemocy to osoba o wyolbrzymionym poczuciu własnej wartości, przeceniająca swoje umiejętności i wiedzę, a także przekonana o własnych zdolnościach i nie przyjmująca krytyki ze strony innych. Zwykle kierowane do niej uwagi ignoruje lub reaguje na nie $\mathrm{z}$ wściekłością i złością. Osoba, która odważyła się mieć odmienne zdanie od lidera mobbingu, jest traktowana jak największy wróg. Osoby uległe również nie mogą czuć się bezpieczne. Mobberzy traktują je jak swoją świtę i klikę, spodziewając się od nich akceptacji dla wszystkich swoich decyzji, nie ufając zwykle nikomu. Ujawniają przy tym małe współczucie dla swoich ofiar. Lidera przemocy cechuje także większa od innych siła i sprawność fizyczna. Mobber jest przeciętnie lub mało popularny w klasie i często otoczony „świtą” dwóch lub trzech osób, które są przez niego szantażowane groźbą użycia siły lub zerwania przyjaźni. Osoby te asystują sprawcy i chronią go przed konsekwencjami. Zwykle o procederze przemocy wie cała klasa, ale ukrywa to przed nauczycielem. Jeżeli nauczyciele nie zauważą zachowań mobbera, będzie on nasilał swoje zachowania. Na skutek tego będzie rósł jego autorytet, a malał prestiż wychowawcy (Gebauer 2007).

Zwykle współczuciem i opieką otaczana jest ofiara przemocy, ale coraz więcej faktów przemawia za tym, że sprawca przemocy sam potrzebuje pomocy. Według badań przeprowadzonych przez Kennetha Rigby i Philipa Slee w 1999 roku, szkolni dręczyciele przeżywają depresję i są na ogół bardziej przygnębieni niż pozostałe dzieci. Ponadto przejawiają wyższą niż średnia skłonność do myśli samobójczych. Badania przeprowadzone przez Olweusa w 1993 roku w Szwecji pokazały, że mobberzy są bardziej skłonni do agresji także w życiu późniejszym, w czasie randek, w zakładach pracy, a kiedy założą własną rodzinę, stają się tyranami. Autor ten wskazuje także na bardzo duże prawdopodobieństwo, że w przyszłości mobberzy zejdą na drogę przestępczą (Rigby 2010).

Warto również wspomnieć o cechach charakteru jednostek doświadczających przemocy rówieśniczej. Otóż charakteryzują się one dużą wrażliwością, nieśmiałością i wysokim poziomem lęku. Ujawniają trudności w nawiązywaniu relacji z grupą. Są pozbawione umiejętności bronienia się, a atakowane - płaczą, wycofują się i uciekają. Posiadają także niską samoocenę. Często towarzyszy im poczucie osamotnienia i opuszczenia. Posiadają także wyższy poziom depresji niż ich rówieśnicy. Najczęściej są słabsze fizycznie od swoich kolegów. Ujawniają lepsze od przeciętnych kontakty z rodzicami i innymi dorosłymi, aczkolwiek relację z matką określają jako nieprawdziwą (Kocemba 2009).

Badacze zjawiska podkreślają, że zarówno sprawca, jak i ofiara mobbingu pod względem kilku cech są do siebie podobni. Odznaczają się pewną „innością”, posiadają nieprzyjemne doświadczenia $\mathrm{w}$ kontaktach $\mathrm{z}$ rówieśnikami we wczesnych okresach życia. Mają także trudności w relacji z matką, które uznają za negatywne. Prawdopodobnie spowodowane jest to brakiem ciepłej, satysfakcjonującej więzi emocjonalnej z matką w okresie wczesnego dzieciństwa. Relacja ta najczęściej miała charakter unikowy, więc więź między nimi została zerwana (Kocemba 2009).

\section{Przejawy i zasięg mobbingu uczniowskiego}

Poznanie zasięgu zjawiska mobbingu w szkole jest zadaniem trudnym i zależy od wielu czynników. Czasami sami dorośli mają trudność w zdefiniowaniu pojęcia przemocy. Niektórzy bagatelizują problem, inni pewne neutralne zachowania klasyfikują jako 
agresywne. Dużym utrudnieniem jest także fakt, że dzieci, które dopuszczają się przemocy wobec swoich rówieśników, zwykle maskują te zdarzenia, a ofiary przemocy wstydzą się przyznać, że były obiektem dręczenia. Podstawowa metoda badająca zjawisko mobbingu polega na zadawaniu dzieciom pytań dotyczących ich doświadczeń ze szkołą. Problematyczne wydaje się także użycie adekwatnego słownictwa w zadawanych im pytaniach.

W literaturze przedmiotu możemy znaleźć dane z badań przeprowadzonych w różnych częściach świata. Jako pierwszy badanie takie przeprowadził Dan Olweus w Norwegii w latach osiemdziesiątych. Przepytał anonimowo ponad 80 tysięcy norweskich uczniów w wieku od 7. do 16. roku życia. Odkrył, że 15\% dzieci było prześladowanych „od czasu do czasu”, a około $3 \% \mathrm{z}$ nich dręczono raz w tygodniu lub częściej (Rigby 2010, s. 40). W latach dziewięćdziesiątych Peter Smith i Irene Whitney w Wielkiej Brytanii przebadali anonimowo 6700 uczniów w szkołach podstawowych i gimnazjach. Odkryli, że $27 \%$ uczniów w szkołach podstawowych i 10\% gimnazjalistów było dręczonych. Ponadto 10\% uczniów szkół podstawowych i $4 \%$ gimnazjalistów doświadczało przemocy raz w tygodniu lub częściej. Natomiast liczba osób, które przyznały się do dręczenia innych wyniosła: $12 \%$ w szkołach podstawowych i 6\% w gimnazjach. W Irlandii Mona O’Moore i jej współpracownicy przeprowadzili ogólnokrajowe badania mobbingu w szkołach podstawowych i w gimnazjach. Uzyskane wyniki wykazały, że prześladowania doświadczało 31\% uczniów szkół podstawowych i 15\% gimnazjalistów w ciągu roku szkolnego. Raz w tygodniu i częściej dręczonych było $4 \%$ uczniów w szkołach podstawowych i $2 \%$ w szkołach gimnazjalnych. Do dręczenia innych przyznało się $26 \%$ uczniów w szkołach podstawowych i $15 \%$ gimnazjalistów (Guerin, Hennessy 2008). Z kolei badania przeprowadzone w Australii objęły ponad 38 tysięcy uczniów z całego kraju w wieku od 7 do 17 lat. Badanie polegało na zastosowaniu Kwestionariusza Relacji Rówieśniczych. Uzyskane wyniki wskazują, że około $16 \%$ respondentów było dręczonych co najmniej raz w tygodniu w trakcie roku szkolnego. Badania przeprowadzone w Stanach Zjednoczonych w 2001 roku pokazują, że przemocy rówieśniczej średnio raz w tygodniu doświadcza w szkole $8 \%$ uczniów w wieku od 12. do 16. roku życia (Rikby 2010, s. 42-43).

Do największych badań międzynarodowych nad problemem mobbingu w szkole należy projekt porównawczy, koordynowany i przygotowany przez Temple University w USA (Piekarska 2008, s.71). Uczestniczyło w nim ponad 20 krajów ze wszystkich kontynentów. Ogółem zbadano ponad 20 tysięcy osób. Do najbardziej dotkliwych przejawów agresji badani zaliczyli sytuacje, w których stosowano terror psychiczny (wyśmiewanie, upokarzanie, straszenie, izolowanie) oraz przemoc fizyczną. Respondenci jako szczególnie traumatyczne ocenili te sytuacje szkolnego mobbingu, w które „zamieszany” był nauczyciel lub wychowawca (Piekarska 2008). Badania przeprowadzone wśród uczniów w szkole polskiej w 1997 i 2003 roku (Libiszowska-Żółtowska, Ostrowska 2008) dowodzą, że zachowania agresywne stają się codziennością. Do grupy uczniów „wolnych od zachowań agresywnych” zaliczono zaledwie $19,8 \%$.

Obserwuje się wyraźne zróżnicowanie w formach przejawianego przez uczniów mobbingu. Mobbing najczęściej przybiera formę przemocy słownej, fizycznej i pozawerbalnej. Do form bezpośredniej przemocy słownej zalicza się: obrażanie za pomocą słownictwa, wyzwiska, ośmieszanie, brutalne dokuczanie i szyderstwa. Pośrednie formy przemocy słownej mogą być wyrażane poprzez: nakłanianie do obrażania i obrzucania wyzwiskami, 
rozsiewanie złośliwych plotek czy wysyłanie obraźliwych esemesów lub e-maili. Innym przejawem mobbingu jest bezpośrednia przemoc fizyczna wyrażająca się poprzez: bicie, kopanie, opluwanie, rzucanie przedmiotami, posługiwanie się niebezpiecznymi narzędziami, bronią. Sposobem pośrednim przemocy fizycznej jest umyślne i nieuzasadnione wykluczanie kogoś z grupy oraz zabieranie i ukrywanie czyichś rzeczy. Znęcanie pozawerbalne w sposób bezpośredni wyraża się poprzez zastraszające gesty, uporczywe wpatrywanie się w ofiarę. Pośrednie znęcanie pozawerbalne polega na ostentacyjnym odwracaniu się plecami do kogoś, komu chce się pokazać, że nie jest mile widziany (Rikby 2010, s. 33).

Mobbing może być również sklasyfikowany jako rasowy - którego powodem jest odmienność rasowa, seksualny - związany z seksualnością lub płcią, oraz elektroniczny - wykorzystujący technologię elektroniczną, np. e-maile, esemesy z groźbami, zakładanie stron szkalujących kogoś (Rikby 2010, s. 33). Ten rodzaj mobbingu jest niezwykle trudny do zbadania. Sondaż przeprowadzony w 2006 roku w Kanadzie wskazuje, że aż 25\% dzieci w tym kraju pada ofiarą użytkowników w przestrzeni wirtualnej. Natomiast w Australii w 2005 roku wskaźnik dzieci padających ofiarą tego typu przemocy wyniósł 14\% (Rikby 2010, s. 44). Wyniki badań z krajów europejskich oraz USA, Australii i Nowej Zelandii, a także z Polski donoszą, że przemocy rówieśniczej (agresja słowna i emocjonalna, fizyczna, seksualna oraz agresja skierowana na przedmioty będące własnością uczniów) w szkole doświadcza od 20\% do 70\% uczniów (Piekarska 2008).

Te wczesne doświadczenia przemocowych zachowań wobec rówieśników, jeśli nie będą w porę zauważone i korygowane, mogą się utrwalać i powodować bardziej wysublimowane formy mobbingu.

\section{Przykłady programów zmierzających do ograniczenia przemocy rówieśniczej}

W literaturze przedmiotu można znaleźć wiele przykładów programów zmierzających do ograniczenia agresji, kierowanych już do dzieci na etapie szkolnym. Jednym z nich jest program Dana Olweusa realizowany w norweskich szkołach. Zakłada on trzy poziomy działania: szkołę, klasę i indywidualnego ucznia. Obszar działań szkolnych obejmuje badania określające rozmiar agresji na terenie szkoły, spotkania pedagogiczne poświęcone zjawiskom agresji oraz spotkania nauczycieli z rodzicami. Obszar działań klasowych zawiera zaradcze środki przeciwko agresji i przemocy (diagnoza, reguły, sankcje, pochwały), realizację programów profilaktycznych, spotkania wychowawcy z rodzicami i uczniami, wspólne zajęcia klasowe (wyjazdy, wycieczki itp.). Obszar działań indywidualnych polega na rozmowach z ofiarami i agresorami, z rodzicami uczniów, zarówno ofiar, jak i agresorów, i podejmowaniu ostatecznych decyzji (przeniesienie do innej klasy, ze szkoły do szkoły). Podstawową zaletą tego programu jest tworzenie w szkole spójnego i przemyślanego systemu całościowego działania przeciwko przemocy (Olweus 2007).

Program wdrażany w szkołach w New Haven zakłada, że agresję można zmniejszyć poprzez kształtowanie umiejętności pozwalających dzieciom lepiej funkcjonować w roli ucznia. Do umiejętności tych zalicza się: słuchanie poleceń i informacji przekazywanych przez dorosłych i rówieśników, tolerancję frustracji, czekanie bez przeszkadzania, posługiwanie się posiadanymi wiadomościami, reagowanie na potrzeby innych oraz umiejętności interpersonalne (Strykowska 2005). 
W Los Angeles został opracowany program autorstwa Normy i Seymoura Feshbachów, którego celem jest zapobieganie agresji poprzez uczenie empatii. Zajęcia obejmowały ćwiczenia z zakresu trzech dyspozycji: zdolności do rozpoznawania cudzych uczuć, umiejętności przyjmowania perspektywy innych osób i wczuwania się w ich rolę oraz zdolności uczuciowej reakcji (Strykowska 2005, s. 145).

Ciekawą propozycją działań zmierzających do ograniczenia przemocy w szkole jest program No blame Approach („Nie winić”), opracowany w latach dziewięćdziesiątych przez psychologów brytyjskich i propagowany przez Barbarę Maines i George Robinsona. Jest on przeznaczony do interwencji w przypadkach mobbingu szkolnego we wszystkich rodzajach szkół. Realizacja programu wymaga współpracy i zaangażowania uczniów, nauczycieli, pedagogów i psychologów szkolnych oraz rodziców. Powszechnie jest oceniany jako wysoce skuteczny. Apeluje do pozytywnych emocji agresorów, wzbudza w nich empatię dla ofiar, nie dążąc do ukarania sprawców przemocy, tym samym nie odwołując się do mechanizmu zastraszania charakterystycznego dla mobberów. Program składa się z siedmiu kroków:

1. Rozmowa z ofiarą mobbingu - poufna, identyfikująca agresorów, biernych uczestników oraz ewentualnych pomocników. W czasie rozmowy wychowawca prosi osobę mobbingowaną o sporządzenie notatki, rysunku lub listu opisującego przykre przeżycia.

2. Zorganizowanie spotkania grupy wsparcia liczącej od 6 do 8 osób, składającej się głównie z odpowiedzialnych pomocników, ale także sprawców przemocy.

3. Przedstawienie grupie problemu, jaki ma ofiara mobbingu i wzbudzenie u obecnych osób empatii. Na tym etapie nie omawia się szczegółów zdarzeń ani nie wini się agresorów.

4. Ujawnienie celu spotkania. W dalszej części informujemy członków grupy, że naszym celem nie jest szukanie winnych, ale wspólna pomoc poszkodowanemu.

5. Wypracowanie przez grupę propozycji pomocy. Każdy uczestnik przedstawia własne pomysły sformułowane według schematu:, Ja zrobię to i to...”.

6. Oddelegowanie grupy. Wychowawca wyraża uznanie, zaufanie i nadzieję, że grupa

7. poczyni pozytywną zmianę.

8. Monitorowanie. Opiekun regularnie prowadzi indywidualne spotkania ze wszystkimi uczestnikami grupy oraz ofiarą przemocy rówieśniczej.

Opisany program skutecznie rozwiązuje przypadki szkolnego mobbingu. Najtrudniejsze sytuacje mogą jednak wymagać dodatkowych, specjalistycznych oddziaływań w dłuższym czasie. Większość poszkodowanych bardzo pozytywnie ocenia efekty interwencji. Nawet specjaliści zdumieni są efektywnością omawianego programu (Piekarska 2008, s. 75-80). Oprócz opisanych wyżej propozycji, szkoły dysponują jeszcze innymi metodami zapobiegania przemocy. Do znanych w Polsce i na świecie należą: Trening Zastępowania Agresji Arnolda Goldsteina, Porozumienie bez Przemocy Marshalla Rosenberga, treningi mediacji, negocjacji czy asertywności (Strykowska 2005).

Pomimo tak szerokiej oferty realizowanych projektów i dokonywanych interwencji zjawisko mobbingu nie maleje, a wręcz przeciwnie - nasila się. Przyczyn tego zjawiska możemy upatrywać $\mathrm{w}$ wielości propozycji, nieodpowiednim przygotowaniu kadry pedagogicznej czy w bagatelizowaniu problemu przez rodziców i nauczycieli. Jednak zagadnienie to wydaje się mieć głębsze uwarunkowania: brak wartości w życiu młodych ludzi. Konieczna 
wydaje się więc współpraca nauczycieli z rodzicami w jednolitym przekazywaniu wartości $\mathrm{z}$ jednoczesnym realizowaniem programów antyprzemocowych.

\section{Przekaz wartości w przeciwdziałaniu zachowaniom mobbingowym}

Przekonanie, że prawidłowy przekaz wartości przez rodziców może ograniczyć prawdopodobieństwo wystąpienia mobbingu ma swoje podstawy. W latach 50. John Bolwby sugerował, że nawiązanie przez rodziców prawidłowej więzi z dzieckiem jest kluczem jego zdrowia psychicznego w późniejszym życiu. Michael Troy i Alan Sroufe w 1987 roku przeprowadzili badania nad biedą w Stanach Zjednoczonych jako możliwym skutkiem zaburzonej więzi lub słabego przywiązania (Troy, Sroufe 1987, s. 166-172). w . W badaniu wzięło udział trzydzieścioro ośmioro dzieci w wieku między 4. a 5. rokiem życia. Zastanawiano się nad możliwymi skutkami różnych typów przywiązania dla ich późniejszych relacji i zachowań interpersonalnych. Dzieci te wcześniej zostały zaliczone do jednej z trzech kategorii przywiązania wyodrębnionej przez Ainsworth: ufnej, unikającej i ambiwalentnej. Badacze skupili się nad ich relacjami z rówieśnikami. Okazało się, że dzieci, które dręczyły swoich rówieśników wykazywały zachowania charakterystyczne dla przywiązania unikającego, a prześladowane sklasyfikowano jako wykazujące przywiązanie ambiwalentne. Dzieci przywiązane ufnie nie zostały dotknięte przemocą szkolną, reagowały tak, jakby zachowania te były im obce albo starały się przekształcić relacje w pozytywne (Rikby 2010, s. 113-114). Jeśli więc przywiązanie ufne jest tak istotne dla zdrowego funkcjonowania dziecka, istotne jest otoczenie go miłością i wzmacnianie jego poczucia bezpieczeństwa.

Rodzice powinni także przeanalizować, w jaki sposób tworzyć bliską i otwartą więź ze swoim dzieckiem od najwcześniejszego okresu. Zbyt wczesne oddanie dziecka pod opiekę placówki o niskiej jakości usług może mieć negatywny wpływ na późniejsze relacje dziecka $\mathrm{z}$ rówieśnikami. Potwierdzają ten fakt dane zawarte $\mathrm{w}$ raporcie sporządzonym w Stanach Zjednoczonych przez National Institute of Child Heath and Human Development w 2006 roku. Autorzy raportu stwierdzają, że prawdopodobieństwo zachowań agresywnych było trzykrotnie wyższe u dzieci, które w wieku czterech i pół roku spędzały w przedszkolu 30 godzin tygodniowo, w porównaniu do dzieci, które przebywały w przedszkolu zaledwie 6 godzin (Rikby 2010, s. 118). Kolejnym czynnikiem mającym wpływ na pojawienie się zachowań mobbingowych może być preferowany styl wychowania w domu. Dzieci wychowywane przez swoich rodziców w sposób wyłącznie autorytarny najczęściej znęcają się nad innymi dziećmi. Jest to zwykle skutkiem naśladownictwa postawy rodzicielskiej, w której dominuje siła (Rigby 2010, s. 120). Niebezpieczne jest także wychowanie określane mianem niewybaczającego. W badaniu przeprowadzonym przez Elizę Achmed i Valerię Braithwaite w 2006 roku stwierdzono, że dzieci, którym rodzice nie wybaczają złego zachowania mogą z dużym prawdopodobieństwem angażować się w dręczenie innych (Rikby 2010, s. 121). Podobnie permisywny styl, w którym rodzic pozwala dziecku na wszystko, czego tylko ono pragnie, może przyczynić się do tego, że dziecko stanie się sprawcą przemocy. Potwierdzają to badania przeprowadzone przez Matthew Curtner-Smithai innych w 2000 roku wśród chłopców w wieku 10 - 13 lat (Rikby 2010, s. 122). Z kolei w pewnych okolicznościach rodzice za wszelka cenę chroniący swoje dzieci przed wszystkim, co mogłoby je skrzywdzić, ograniczają relacje dziecka z rówieśnikami, nie pozwalając na rozwój jego kompetencji społecznych i komunikacyjnych. 
Dan Olweus na podstawie badań własnych przeprowadzonych w 1993 roku stwierdził, że nadopiekuńczość matki czyni dziecko bardziej podatnym na znęcanie się nad nim (Rikby 2010, s. 123). Natomiast badania Jill Bates i Kathy Bayles dowodzą, że matki bardzo uczuciowo związane ze swoimi dziećmi nie miały z nimi żadnych problemów w wieku późniejszym (Guerin, Hennessy 2008, s. 25).

Z powyższych badań wynika, że wartości muszą zostać nazwane i jasno wyartykułowane przez dorosłych: o czym mówi dana wartość i czego oczekują oni od dzieci w różnych sytuacjach. Dlatego przede wszystkim dom rodzinny, a później szkoła powinny być miejscem przekazu wartości, bo tutaj zaczyna się wychowanie człowieka. Rodzice muszą posiadać hierarchiczny system wartości, solidny i konstruktywny. Wartość podstawowa, jaką rodzina wybierze, powinna pociągać za sobą nieuchronnie inne, aż do utworzenia struktury. Jeżeli wybiera się jako wartość godność osobistą, to implikuje ona również pokój, życie i ekologię, a te z kolei wartości generują wolność, odpowiedzialność, solidarność, zdolność tworzenia i życie wewnętrzne. Dopiero ich naturalną konsekwencją będą bardzo konkretne postawy codzienne: przyjaźń, dobroć, zrozumienie, uprzejmość, wierność, zaufanie, szlachetność, szacunek itd. (Ferraro 1999). Wynika z tego, iż postawy wyuczone $\mathrm{w}$ domu powinny być usprawniane $\mathrm{w}$ szkole $\mathrm{i} \mathrm{w}$ relacjach $\mathrm{z}$ rówieśnikami.

Kolejnym ważnym aspektem jest uczenie wartości. W odniesieniu do zachowań mobbingowych należy podkreślić, że to, czy dziecko będzie miało problemy z przemocą w szkole, jest uzależnione nie tylko od czynników genetycznych, ale nade wszystko od ważnych grup odniesienia, zwłaszcza domu rodzinnego, rówieśników i szkoły. Wielu badaczy zwraca uwagę na fakt, że dzieci doznające przemocy w szkole nie mają przyjaciól. Powoduje to, że stają się one podatne na zranienia, ponieważ gdy zostaną zaatakowane, nie mają nikogo kto chciałby im pomóc. Ważnym przekazem domu rodzinnego dziecka jest więc stworzenie przestrzeni wolności, aby mogło ono spotykać się i zaprzyjaźnić z innymi, a przez to usprawniać swoje kompetencje społeczne. Rodzice mogą także pomóc dziecku w rozpoznaniu i rozwijaniu określonych umiejętności i zainteresowań. Dzięki temu będzie mogło ono rozwijać swoje zdolności, ale także konstruktywnie nawiązywać nowe znajomości z osobami o podobnych pasjach. Najistotniejszy wydaje się jednak sam przykład rodziców w obecności dziecka, gdyż wartości rodzą się z kontaktu: w jaki sposób rodzice zawierają znajomości? Jakie relacje mają ze swoimi znajomymi i jak te relacje podtrzymują? Co mówią o swoich znajomych podczas ich nieobecności? Uczą w ten sposób szacunku i pozytywnego nastawienia do innych. Ważne wydaje się także kształtowanie właściwych postaw wobec siebie i innych, z których będą wynikały adekwatne do sytuacji reakcje, np. dziecko potrafi wstawić się za osobą źle potraktowaną. Można uczyć dzieci elastyczności w skutecznym radzeniu sobie w szkolnych konfliktach.

Reasumując, należy mocno podkreślić, że nawet najlepsze programy i projekty profilaktyczne nie będą skuteczne, jeżeli młody człowiek nie zakorzeni się w wartościach uniwersalnych, takich jak m.in. dobro, i nie zostanie wyposażony w ten system wartości przez mądrych dorosłych w domu i w szkole. Programy profilaktyczne mogą być pomocne w wychowaniu młodego pokolenia. Są one jednak zawsze wtórne do przekazu wartości, które młode pokolenie powinno otrzymywać jak najwcześniej w jasno określonej formie, tak by w chwilach próby miały one wpływ na jego zachowanie. 


\section{Zakończenie}

Mówienie o przemocy rówieśniczej powinno być rozpatrywane i interpretowane w szerokim kontekście, zgodnym z definicją Kena Rigby, która mówi, że jest to „umyślne nadużywanie władzy bądź siły w relacjach międzyludzkich”. Przyjęcie tej definicji pozwoli wychowawcom na jednoznaczną identyfikację zachowań przemocowych i umożliwi skuteczną interwencję zarówno w przypadku drażnienia ofiary, jak i znęcania się nad nią. Zwłaszcza że wszyscy uczestnicy przemocy szkolnej wymagają pomocy, a skala zjawiska ciągle rośnie. Praca profilaktyczna z młodzieżą wymaga zapoznania się z procesami dynamiki grupy i $\mathrm{z}$ wewnętrznymi procesami zachodzącymi w poszczególnych osobach. W taki sposób kształtuje się umiejętność rozwiązywania problemów i doskonalenie zdolności członków grupy w tym zakresie. W pracy z dziećmi i młodzieżą należy uwzględnić i rozwijać życzliwą uwagę, empatię, doświadczenie oraz poczucie własnej wartości.

Należy pamiętać, że skuteczne zapobieganie mobbingowi międzyuczniowskiemu możliwe jest przede wszystkim poprzez kształtowanie systemu wartości i częste odwoływanie się do niego w domu i w szkole. Dzieci muszą poznać wartości, w które wierzą ich rodzice, i reguły, które należy respektować. Muszą rozumieć, że łączy się to z pewną odpowiedzialnością i że wartości rodzą się niejako z kontaktu $\mathrm{z}$ innymi. W rodzinie dziecko doświadcza poczucia bezpieczeństwa, tam tworzy więzi. Przywiązanie ufne jest ważne dla zdrowego funkcjonowania dziecka, gdyż chroni go przed uwikłaniem się w przemoc uczniowską w przyszłości. Ponadto wiek, w którym dziecko zostanie oddane pod opiekę placówki, i jakość świadczonych w niej usług może mieć ogromny wpływ na późniejsze relacje dziecka z rówieśnikami. Nie bez znaczenia w profilaktyce zachowań przemocowych jest także styl wychowania preferowany przez rodziców. Nie można nakazać dziecku być dobrym i mądrym, ale można pomóc mu kształtować te postawy w relacji z nim. Brak poczucia bezpieczeństwa, wsparcia, wzorów i autorytetów powoduje, że młody człowiek podąża za popędami, a nie wartościami.

Szeroki wybór istniejących programów profilaktycznych znacznie wspiera tworzenie odpowiedniego sposobu działania w sytuacjach przemocy uczniowskiej. Jednak fundamentalną istotą wychowania powinno być przekazywanie młodym ludziom wartości na tyle wcześnie, aby w przyszłości miały one wpływ na ich zachowanie, a nawet mogły chronić przed niekorzystnymi zjawiskami społecznymi.

\section{Bibliografia}

Aronson E., Wilson t. D., Alert R. M. (1997). Psychologia społeczna. Serce i umysł. Poznań: Wydawnictwo Zysk i S-ka.

Ferraro B. (1999). Rodzice szczęśliwi. Warszawa: Wydawnictwo Salezjańskie.

Gebauer K. (2007). Mobbing w szkole. Warszawa: Instytut Wydawniczy PAX.

Guerin S., Hennessy E. (2008). Przemoc i prześladowanie w szkole. Gdańsk: Gdańskie Wydawnictwo Psychologiczne.

Grochulska J. (1982). Reedukacja dzieci agresywnych. Warszawa: Wydawnictwa Szkolne i Pedagogiczne.

Kmiecik-Baran K. (200o). Młodzież i przemoc. Warszawa: Wydawnict wo Naukowe PWN. Kocemba I. (2009). Ci, którzy dręcza innych. „Psychologia w szkole”, nr 1(21), s. 132-139. 
Meissner W. K. (1988). Ludzka płciowość i jej znaczenie. W: Rzepka J. (red.). Zagadnienia prorodzinnej edukacji seksuologicznej i profilaktyki HIVIAIDS. Katowice: Studio Wydawnicze AGAT.

Olweus D. (2007). Mobbing. Fala przemocy w szkole jak ja powstrzymać? Warszawa: Jacek Santorski \& Co Agencja Wydawnicza.

Ostrowska K. (2005). Zachowania agresywne w środowisku szkolnym. W: Ostrowska K., Surzykiewicz J. (red.). Zachowania agresywne w szkole. Warszawa: Centrum Metodyczne Pomocy Psychologiczno-Pedagogicznej.

Pervin L. A. (2005). Psychologia osobowości. Gdańsk: Gdańskie Wydawnictwo Psychologiczne.

Piekarska A. (2008). Mobbing - niebezpieczna bomba w szkole. „Psychologia w szkole”, nr 3 (19), s. 69-80.

Rigby K. (2010). Przemoc w szkole. Jak ja ograniczyć? Poradnik dla rodziców i pedagogów. Kraków: Wydawnictwo Uniwersytetu Jagiellońskiego.

Strykowska J. (2005). Niedostosowanie społeczne dzieci w wieku szkolnym. Gniezno: Gnieźnieńska Wyższa Szkoła Humanistyczno-Menedżerska MILENIUM.

Surzykiewicz J. (2005). Agresja i przemoc w szkole w świetle ogólnopolskich badań nauczycieli w latach 1997 i 2003. W: Ostrowska K., Surzykiewicz J. (red.). Zachowania agresywne w szkole. Warszawa: Centrum Metodyczne Pomocy Psychologiczno-Pedagogicznej.

Troy M., Sroufe L. A. (1987). Victimization among preschoolers: Role of attachment relationship history. "Journal of American Academy of Child and Adolescent Psychiatry", nr 26, s. 166-172.

\title{
THE PHENOMENA OF MOBBING AMONG STUDENTS AND THE TAKE-HOME VALUES
}

\begin{abstract}
The article includes information on school violence in context of proper transmission of values. The definition of mobbing has been analysed and the role of both the violator and the victim of the violence in the above-mentioned aspect have been described. The further part of the article consists of the outcomes of the research on student mobbing in various countries. The forms of violence have been listed. Chosen preventive programs which aim at mobbing limitation have been described. The article tackles the issue of values which could minimise the risk of a child becomming a victim of violence or of the fact that they might become a mobber themselves.
\end{abstract}

Key words: violence, aggression, mobbing, mobbing victim, mobber, mobber'spersonality, antymobbing programmes, values

Romualda Małgorzata Kosmatka - magister pedagogiki i magister psychologii, zatrudniona w Zespole Poradni Psychologiczno-Pedagogicznych w Pile i w Państwowej Wyższej Szkole Zawodowej w Pile. Absolwentka Wydziału Nauk Społecznych Katolickiego Uniwersytetu Lubelskiego i Wydziału Nauk Społecznych Uniwersytetu im. Adama Mickiewicza w Poznaniu. Adres do korespondencji: ul. Stańczyka 2, 64-920 Piła. Adres e-mail: kosapil@wp.pl 